LELIA GREEN

\section{understanding celebrity and the public sphere}

It was once said of one of my colleagues that 's/he (gender not specified!) bore the imprint of the book s/he'd most recently finished'. It's difficult to read either of the two books reviewed here and not be influenced by the experience. Although they are very different books, examining their specific focus of interest from very different perspectives, there is an element of explicit overlap-as in Turner's chapters on 'Celebrity, the Tabloid and the Democratic Public Sphere', and his 'Conclusion: Celebrity and Public Culture Today'; and in McKee's focus on trivia, commercialisation and spectaclearguably elements of public culture popularly associated with celebrity reporting. Notwithstanding this overlap in content, there is significant variance in tone and approach between the two books (with 'the public sphere' getting responsible but playful consideration and 'celebrity' being treated very seriously).

The reader of Graeme Turner's Understanding Celebrity feels confident that every contribution to this debate has been analysed and mined for nuance and significance. The cover could legitimately proclaim, 'If you only ever read one book on celebrity, this is the one to choose: it saves having to read all the others'. Alan McKee, on the other hand, is consciously engaging the reader in a critical debate which he constructs as starting with his book and continuing afterwards. He's arguing for a new conception of the public sphere. Essentially, McKee suggests, there is ample evidence that the public sphere is increasingly trivialised, commercialised, dominated by spectacle, fragmented and associated with an apathetic response to traditional forms 
of political engagement. However, he argues, this is a cause for celebration because the 'old model' ('modernist' construction) of the public sphere suited and benefited an influential minority in society (white, middle-class, educated males) and the new model of the ('postmodern') public sphere increasingly engages the sectors of society systematically excluded and marginalised by modernity's view of what the public sphere should be and does.

The impact of McKee's book is to encourage the reader to think and read more. In particular, there's a unique-in my experience-aside to the reader where McKee confesses: 'The original draft of this chapter was three times as long as the current one. If you would like to read a full account of these issues, please email the author on<a.mckee@qut.edu.au> and I'll send you a complete version.'(224) This is not the only page where a sense of evangelical fervour is communicated. If Turner's book wins respect from peers, colleagues and disciples in academia, McKee's is likely to win the hearts and minds of a generation of undergraduates. Both books, as might be anticipated, are excellent at what they set out to do. The nature of that excellence will be illustrated here by predominantly adopting the organising framework of one book (McKee's) and using it to discuss the ideas and provocations of both.

McKee's book is divided into six parts. The introduction is an exciting construction of critiques regarding the nature of the public sphere as being disguised battles about its inclusivity. Is Habermas's ${ }^{1}$ conception of the public sphere in fact a valorisation of white, middle-class, educated, masculine values concentrating on 'serious issues of real importance ... party politics' using 'rational, logical' debate, refusing to 'dumb down to consumers' challenging them instead to 'work harder to improve themselves' (McKee 14)? Is the experience of trivialisation, commercialisation, spectacle, fragmentation and apathy (McKee's organising principles) actually evidence of a struggle for the inclusion of values representing perspectives other than dominant middle-class masculinity? If so, then understanding celebrity-Turner's projectalso takes on an additional nuance. The review essay that follows will take each of McKee's organising principles and consider it in terms of the arguments and contribution to the debate from each of the two books.

\section{TRIVIALISING THE PUBLIC SPHERE}

McKee aligns the notion of 'trivia' with the private and the personal-'the emotional side of relationships, raising children, keeping households together'. (36) He goes on to associate 'the personal' with women's struggle for equality ('the personal is political'), constructing the increase in discussion of private matters within public culture as an indication of progress towards the feminisation of the masculine public sphere. Turner's contribution to an understanding of the trivial is to explain that this emphasis on the private is treated as a deadly serious professional responsibility by those who are charged with claiming column inches for their clients: the public relations and publicity professionals: 'When we conceptualise celebrity as something to be professionally managed, rather than discursively deconstructed, we think about it differently'. (136) 
One example given by Turner (citing ductive and professional work. (40) The 'trivia' Young) $)^{2}$ is of Tom Cruise's PR management of discussions of celebrity lives thus revolve rejecting 'fourteen writers before deciding on around the home, the hearth and the heart, one who was deferential enough to interview all of which are traditionally women's work, Tom Cruise for Rolling Stone'. (36) However, the and gossip, which is traditionally a mainstay dynamic and developing process of the con- of women's networks, although McKee (39) struction and management of celebrity itself makes clear that some gossip-as far back as constitutes an example of 'the tipping point', the French Revolution, or as recently as Lewin'the name given to that moment in an epidemic sky's blue dress-is deadly political.

when a virus reaches critical mass'. ${ }^{3}$ There comes a moment in time and fame where a celebrity's publicists no longer court the media, but where the media pay homage to the celebrity (and kowtow to their minders). Young's comments on Tom Cruise's PR management indicate that such a point had been reached in 2001, with respect to Rolling Stone at any rate.

But McKee's argument about the association of the trivial with women's work is one that repays deeper interrogation. Almost a generation ago, Virginia Nightingale commented

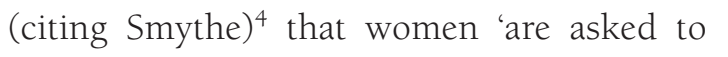
forget that watching television is also work, to see television advertisements not as a continual reminder of the work of purchasing, but as entertainment'. ${ }^{5}$ Yet if the task of managing a household's consumption is predominantly a female one, it is one that can be validated and given more status and romance by access to information about the consumption choices of conspicuously wealthy celebrities. In his discussion about 'the close relationship between celebrity and the consumption of commodities', Turner points out that the celebrity is regularly portrayed as 'a model of consumption practice If I do have a complaint about McKee's book, it and aspiration' rather than as a model of pro- is that it can be dogged in the thoroughness 
with which it argues the difference between the 'modern public sphere' (rational, middle-class, masculine, Anglo-centric, educated, monolithic) and the 'postmodern public sphere' (emotional, multi-class, inclusive of genders, cultures and educational experience, fragmented and diverse). Having established, provocatively and playfully, how he was going to deal with the matter of the allegation of trivialisation of the public sphere, McKee then follows his model with the dedication of a preacher. Thus his major approaches and arguments regarding trivialisation are revisited in subsequent chapters.

The first indication of this doggedness-inaction is presented in the discussion of the commercialisation of the public sphere. In McKee-talk, 'commercialisation' is the name given by middle-class (gendered) elites when confronted by an expanded public sphere relevant to the culture, interests and passions of working-class people. (66) He argues that the cultural difference between the classes is exposed though charges such as 'the dumbing down' of contemporary media, and appeals to 'the lowest common denominator'. McKee's examples of such commercialised products are drawn from recent (past-decade) mass media television successes-Big Brother, Queer Eye for the Straight Guy, Oprah, ${ }^{8}$ Wife Swap. These programs, says McKee (citing Aaronovitch) ${ }^{9}$, constitute an important contribution to the public sphere because trashy media "'constantly reminds you of that most easily forgotten thing of all; the possibility of something else [...] an explanation" for the behaviour of people from backgrounds different from your own'. (102)
McKee argues that offering a range of possibilities via the public sphere effectively enriches cultural vibrancy and potential while validating a diversity of differing cultures. (Turner also discusses 'trivia' and 'commercialisation'-for example in his examination of tabloidisation and the production of celebrity.) (78-85)

Earlier, McKee questions relationships between identity and the public sphere: 'What's the link between someone's identity, the culture they belong to and the kinds of knowledge they possess?' (87) Positing the idea that different public cultures are on offer to members of different classes, McKee suggests that 'workingclass people have grown up in cultures that value spontaneity, disrespect, vulgarity and interactivity' (88), even if this does not describe the culture of all working-class people across all circumstances. When the public sphere is characterised by a restrained, rational, serious and uncommercialised culture, this makes it easier for 'formally educated people' (88) to understand and participate in debates while simultaneously making it more difficult for members of other cultural groups to do so (93).

The resonance I perceive with Turner's work here is with his definition of celebrity as 'a cultural formation that has a social function we can better understand'. (9) Increasingly, he says, it is 'implicated in debates about how individual identities are constructed in contemporary cultures, and about how the individual self is culturally defined'. (9) He argues that entertainers colonise the category 'celebrity' because 'they are skilled in the marginal differentiation of their personalities'. (5) Whereas McKee uses his argument about the commercialisation 
of the public sphere to address the link between identity and culture, Turner does this through arguing that a critical contribution made by celebrities to everyday life is via a range of cultural inputs which influence an individual's relationship with culture and identity $(102-7)$.

Turner suggests that the individual's 'real relationship' with a physically remote celebrity (whom a fan or follower is unlikely to have ever met) is via the celebrity's provision of raw material for 'the construction of identity through cultural consumption.' (102) Within the public culture of the time, Turner argues, the death of Diana, Princess of Wales, represented an 'abrupt end' to the public entertainment value and commodity value of this celebrity narrative. (101) He claims that 'the eruptive and unforeshadowed character' of her death shocked people in both an authentic and mediated way. (98) This assertion follows Karin Becker's argument that public reactions to Diana's death illustrate that any dichotomy between 'mediated' and 'real' can no longer be constructed as either/or, but instead has to be characterised as and also. ${ }^{10}$

Suggesting that her public had become used to Diana's availability for their 'identity work', Turner goes on 'to stress the importance of the playfulness of so much of our consumption of celebrities. The construction of [our] identity is at least as much play as work'. (102) He suggests that celebrity awareness 'is as likely to produce a playful and imaginative form of cultural consumption as it is to unproblematically support the interests of capital'. (102) McKee also critiques the Marxist concept of trashy cul- ture as a capitalist plot: 'Is trashy culture after all not working-class culture but capitalist culture imposed on the working classes?' (86) He answers emphatically in the negativeworking-class audiences are not dupes, fooled into believing something that's fed to them by capitalist interests. (87) Instead, they're interpretive, critical, 'fickle' and creative in their 'unexpected uses' of the material presented to them by the public sphere. Further, McKee argues that 'this vulgar, sensationalised culture in the official public sphere [is] a hopeful sign of increasing popular access to the public sphere.' (87)

Having addressed the tipping point at which media/celebrity tables turn (when the media courts the celebrity, rather than vice versa), Turner goes on to examine the moment at which people realise that a celebrity is not peripheral, but central, to their construction of culture. (98) The death of Diana was a critical instance of this: 'At such a point, the precise cultural function performed by a figure such as Diana seemed to be in urgent need of examination.' (89) Turner describes the paradox in which "while whole industries devote themselves to producing celebrity, the public remains perfectly capable of expressing their own desires as if the production industry simply did not exist.' (91) Celebrity 'from below', he argues, 'is a mode of consumption, and it is powerful.' (91) That power to engage, in Turner's mind, calls into question the dismissal of the relationship between a celebrity and his/her 'consumer audience' as a 'parasocial' one. Instead, argues Turner (drawing in part on the work of Chris Rojek): ${ }^{11}$ 
the social and physical remoteness of the celebrity $[\ldots]$ is massively compensated in the contemporary world by the amount of contact-highly personal contactavailable through mass-mediated representations. [...] [R]ecent evidence on the consumption of celebrity would suggest a far more fundamental—be it social, cultural or even religious-function being served than is consistent with descriptions that see it as a merely compensatory, second-order practice. (94)

If a focus on celebrity culture is part of media's trashiness, it is nonetheless important.

\section{SPeCtacle AND THE PUblic SPHERE}

While Diana's life as a princess can be constructed as a 'spectacular' colonisation of the public sphere, McKee associates spectacle (the way in which issues are discussed, as well as the kinds of topics discussed) with Black culture, and especially focuses upon an analysis of rap music. (105) McKee celebrates the rap band Public Enemy's song 'By the Time I get to Arizona' as an example of what he means by spectacle-'a performed piece':

[I]t's embodied and its argument consists of more than just [the] words read out. It's rapped, offering the visceral pleasure of rhythm and performance. It comes with a music video that uses visual techniques to add to the message: it shows politicians being shot, and ends with a massive explosion $[\ldots]$ it uses forms of communication far outside the official and respectable forms of rational political philosophy. (106)

This 'visual, aural and bodily' communication, says McKee, is as important to the Black public sphere as 'written rational modes of communication are to traditional Western philosophers' (107) and he goes on to assert that 'different cultures have traditionally employed different kinds of public communication'. (111) The question posed by the inclusion in the public sphere of the spectacle, and its forms of emotional communication, 'is whether we should respond to this fact by accepting that all cultures' forms of communication are equally good; or by arguing that some are better [...] and that all citizens should have equal access to the better ones.' (111)

In some ways Turner's arguments about the rise of celebrity culture parallel McKee's when he states that some commentators and 'public intellectuals' tend 'to regard the modern celebrity as a symptom of a worrying cultural shift: towards a culture that privileges the momentary, the visual and the sensational over the enduring, the written and the rational.' (4) The construction of 'the spectacle' as a technique for distracting people from the important affairs of life has been a complaint of critics of spectacular entertainments since (at least) the time of Juvenal (c 60-130): 'Two things only the people anxiously desire-bread and circuses'. ${ }^{12}$ To my mind, Turner's discussion of spectacle as an example of complexity in the public sphere falls more easily into the expected 
uses of the term than does McKee's commentary upon rap music: 'celebrity-as a discourse, as a commodity, as a spectacle-is marked by contradictions, ambiguities and ambivalences.' (Turner 109)

Crediting Lynn Spigel's ${ }^{13}$ contribution to the debate, Turner argues that 'the ability of television to create a sense of "being there" produce[s] a kind of hyperrealism', effectively a more spectacular view of an event, personality or dramatic moment that those physically present would ever be able to experience. (114) For me, one of the more spectacular and unsettling contemporary uses of the media is the web-posting of atrocities (beheadings, suicide bombs) by terrorisers engaged in political 'debate' in countries such as Iraq. For every politically motivated hostage execution, a hundred (or maybe a thousand times more) Iraqi civilians have been affected as a result of Western interventions in the affairs of their country. Nonetheless, the impact of the scale of Iraqi civilian tragedy is less evident to remote audiences than the terrorist-managed spectacle which claims an increasingly important role within the public sphere and unfortunately catapults hapless victims (such as Ken Bigley) to the status of celebrities.

\section{THE FRAGMENTATION OF THE PUBLIC SPHERE AND AUDIENCE APATHY}

It is with the final two chapters of McKee's book that the significant overlap between his work and Turner's ends. Whereas McKee goes on to address issues of fragmentation of the public sphere (via discussion of the diversity of culture, as represented by the rising importance of Queer concerns and debates to broader cultural discussion), and examines the notion that contemporary popular culture breeds apathy, Turner's significant contribution to furthering debate may be through his introduction of the idea of the 'demotic turn'. This latter concept has no parallel in McKee's book and is dealt with separately in the following segment.

McKee discusses Queer cultural debate in terms of what Daniel Dayan ${ }^{14}$ might call the 'micro public sphere'. While Dayan specifically considers cultural 'diasporas', he assigns a critical role to 'particularistic media', used to sharing meanings within a community and between dispersed elements of that community. As I have written elsewhere:

particularistic media [are] elements that circulate understandings between people who have already constructed a shared past; media used to keep a group in contact, rather than media used to form a group of like interests. These are 'media whose aim is not to create new identities but to prevent the death of existing ones'. (Dayan 110)

Such studies of diasporic communities have relevance to studies of other psychological, dispersed and virtual communities. ${ }^{15}$

McKee considers such big questions by drawing on Joshua Meyrowitz's insights about technology's role in building accessibility to conversations from which a person might normally be excluded (giving the example of how, some 
generations ago, middle-class men and women would withdraw to different rooms after dinner to engage in gender-specific discussions). The new visibility and accessibility of different-sometimes competing, sometimes overlapping-public spheres allows the development of greater understanding across, between and within diverse taste cultures. In particular, it becomes comparatively easy for non-target groups to consume media produced for other communities 'no matter which culture you personally feel most comfortable with.' (144)

In illustrating 'fragmentation' and the multiplicity of public spheres, McKee argues that a major contribution of Queer activists and spokespeople is their argument for 'diversity rather than uniformity: and they [Queer activists] argue that it's possible to have real debate even if people are speaking from within different paradigms and different demographic cultures'. (146) He identifies three major criticisms put forward by 'modern' commentators against the fragmentation of the public sphere into a diversity of (micro) public spheres: it draws attention away from the 'legitimate' public sphere where matters of importance are decided; it encourages people to selfishly consider their own social interests at the expense of society generally; it complicates mechanisms through which different groups can communicate with each other since there is no guarantee that that all share a common currency in participating in the same public sphere. He counters these concerns by suggesting that a key contribution made by the 'limited public spheres of particular identities' is that these allow diverse publics to 'work out what their interests are in order to bring them to discussion in the national public sphere'. (154) Essentially, recognising the fragmentation of the public sphere (which McKee suggests was only ever unified in theory) honours the legitimacy of a range of publics and acknowledges their right—individually and collectively_to bring matters of concern to wider public spheres. One example of this dynamic is the issue of gay marriage-first raised in Queer public space and then exported to the 'official' public sphere. (170)

McKee's final defence of postmodern constructions of the public sphere is against the charge that popular culture breeds political apathy. Using the example of youth culture, McKee's view is that this is a definitional matter. Citing Nancy Fraser, ${ }^{16}$ he argues that whereas political action might have previously been constructed as campaigning for legislation to distribute resources more equitably, a new social movement such as youth activism 'aims to change culture rather than legislation, and hopes for recognition rather than redistribution.' (174):

The form of politics associated with youth movements-for several decades nowisn't the traditional one. It isn't the world of political parties, general elections, doorknocking and lobbying. It is, rather, the politics of new social movements [...] It's cultural politics-attempts, as with culture jamming, to change the world through performance, theatre, entertainment and ideas. (182) 
McKee sums up his discussion on apathy by suggesting that, given that 'cultural politics is real, then it makes sense to argue that the consumption of culture is part of the political process'. (196) Such a reading constructs contemporary western society as the most politically engaged citizenry in history. Consequently, it is of little surprise that McKee's final chapter ('Conclusion' 204-16) is an argument for optimism, as well as for postmodernism.

\section{THE DEMOCRATISATION OF CELEBRITY AND THE DEMOTIC TURN}

So far, in discussing the overlap between McKee's and Turner's work, I feel I have not adequately addressed the contribution to a new understanding of celebrity made by Turner. Apart from the industrial and other aspects of the production of celebrity-which have been addressed in terms of the public sphere-I see his discussions (17) of the nature of fame (for example, his argument that 'fame has been disconnected from achievement') and of 'DIY celebrity' as particularly enlightening.

Fame and celebrity are harnessed to different ends. Thus a sports star might be constructed in terms of a nationalistic or ethnocentric discourse, as a 'role model' and as someone whom fans (or 'the country') can admire (105-6) while (what some might construct as) the 'undeserved'-and usually temporary—fame of a reality TV contestant or 'accidental celebrity' might be harnessed to the celebration and validation of 'the ordinary', thus integrating a sense of the ordinary within that of celebrity. Instances cited by Turner include 'DIY celebrity: cam-girls' (63-9) and a suggestion that the motivation for 'the media's mining of the ordinary seems to be its [the ordinary's] capacity to generate the performance of endless and unmotivated diversity for its own sake'. (83) This diversity, he argues, (84) means that celebrity has begun to mutate 'from being an elite and magical condition to being an almost reasonable expectation of everyday life in the twenty-first century', and has the potential to free the individual 'from insignificance'. (Bourdieu, cited by Turner, 61)

Turner makes a point of distinguishing between the demotic-'of or belonging to the people ... popular, vulgar'17 — and the democratic (which is how McKee constructs the explosion of diversity in the public sphere):

The 'democratic' part of the 'democratainment' neologism is an accidental consequence of the 'entertainment' part and is the least convincing component. It is important to remember that celebrity remains an hierarchical and exclusive phenomenon, no matter how much it proliferates [...] [M] aybe what we are watching in the demotic turn is the celebrity industries' improved capacity [to disavow the exclusivity of celebrity] convincingly through the media. (83)

While this could be taking as re-inscribing the discourse of the 'duped audience' upon the cultural consumer, Turner returns to his view that the useful side-effect of the demotic turn is the proliferation of cultural material for identity construction. Leading (in part) to his discussion of 'celebrity from below', Turner 
attributes Diana's popularity to the dynamic of of 'celebrity culture' in our media-saturated the demotic turn: 'At a cultural moment when world-The Public Sphere: An Introduction was it is the ordinary rather than the elite that is in pitched as a starting point for debate and thus the discursive ascendancy, the rest of the royal wasn't explicitly addressed to me-after all, family probably never had a chance in the com- I've studied and written on the public sphere petition for the public interest and it seems the myself. ${ }^{18}$ McKee's book was consequently an public would not forgive them for failing to unexpected treat and all the more delicious as realise that'. (96) a result of its piquant disregard of many aca-

Excitingly, for the reader (if not for Turner), McKee's book could be taken as a response to a challenge explicitly offered in Understanding Celebrity, such as the following:

There is no necessary connection between demographic changes in the pattern of access to media representation and a democratic politics. At the empirical level, for every Oprah Winfrey there is a Rush Limbaugh. At the structural level, no-one has yet even attempted to properly argue such a connection-it has simply been assumed [...] Diversity, it would seem, must be intrinsically democratic. (82)

Readers would have to draw their own conclusions as to whether McKee's book is a convincing response to the gauntlet offered by Turner. As McKee suggests, 'This is an attitudinal difference that can't be resolved [by appeal to fact or rational argument]'. (27, and elsewhere)

\section{ConCLusion}

Lelia GREen is Professor of Communications in Edith Cowan University's School of Communications and Contemporary Arts. She is also author of Technoculture: From Alphabet to Cybersex (Allen \& Unwin, 2002) and a Chief Investigator of the ARC Centre of Excellence for Creative Industries and Innovation.

While I felt that Understanding Celebrity was 'written for me' in that it was pitched to be what I expected and hoped-a deep engagement with the phenomenon and implications

1. Jürgen Habermas, The Structural Transformation of the Public Sphere: An Inquiry into a Category of Bourgeois Society, trans. Thomas Burger and Frederick Lawrence, MIT Press, Cambridge Mass, 1989 [1962]. 
2. Toby Young, How to Lose Friends and Alienate People, Little, Brown \& Co, London, 2001.

3. Malcolm Gladwell, 'The Tipping Point', <http:// www.gladwell.com/tippingpoint/>.

4. Dallas W. Smythe, Dependency Road: Communications, Capitalism, Consciousness, and Canada, Ablex, Norwood, NJ, 1981.

5. Virginia Nightingale, 'Women as Audiences', in MaryEllen Brown (ed), Television and Women's Culture: The Politics of the Popular, Currency Press, Sydney, 1990, p. 33.

6. Barbaralee Di Diamonstein, 'We Have Had Abortions', Ms Magazine, preview issue, Spring 1972, pp. 34-5.

7. Susan Edmiston, 'How to Write your own Marriage Contract', Ms Magazine, preview issue, Spring, 1972, pp. 66-72.

8. Turner, citing Shattuc, also addresses the moral panic surrounding the 'Oprahfication' of America', p. 78.

9. David Aaronovitch, 'Why We Love Wife Swap', Observer, 5 October 2003, p. 23

10. Karin Becker, 'The Diana Debate, Ritual', Screen, vol. 39, no. 3, 1998, pp. 289-93.

11. Chris Rojek, Celebrity, Reaktion, London, 2001, p. 52 .

12. Juvenal, Satires, vol. 10, no. 1, pp. 80-1.

13. Lynn Spigel, Welcome to the Dreamhouse: Popular Media and Postwar Suburbs, Duke University Press, Durham, NC, 2001, p. 46.

14. Daniel Dayan, 'Particularistic Media and Diasporic Communications', in Tamar Liebes and James Curran (eds), Media, Ritual and Identity, Routledge, London, 1998, p. 103.

15. Lelia Green, Communication, Technology and Society, London, Sage, 2001, p. 130.

16. Nancy Fraser, 'Recognition without Ethics?', in Scott Lash and Mike Featherstone (eds), Recognition and Difference: Politics, Identity, Multiculture, Sage, London, p. 21.

17. The Shorter Oxford English Dictionary on Historical Principles, third edition, vol. 1, Oxford University Press, Oxford, 1973, p. 517.

18. Green, pp. 116-32. 